\title{
Assessing Genotoxic Potential of Cotinus Coggygria Scop: Using the Mussel Micronucleus Test
}

\author{
Bettina Eck-Varanka ${ }^{1}$, Nora Kováts ${ }^{1 *}$, Eszter Horváth ${ }^{1}$, Katalin Hubai ${ }^{1}$ and Gábor Paulovits ${ }^{2}$ \\ ${ }^{1}$ Department of Limnology, University of Pannonia, Hungary \\ ${ }^{2}$ Balaton Limnological Institute, Centre for Ecological Research, Hungarian Academy of Sciences, Hungary
}

\begin{abstract}
Introduction: Cotinus coggygria Scop. is widely used in ethnopharmacology such as antiseptic, anti-inflammatory, antimicrobial, hepatoprotective, as well as for countering diarrhea, gastric and duodenal ulcers. Total phenols, flavonoids and tannins were determined as the main group of biologically active compounds. Tannins, however, have proven mutagenic in different studies. Also, methanol extract of $C$. coggygria induced sex-linked recessive lethal mutations on the X-chromosome of Drosophila melanogaster males.
\end{abstract}

Materials and methods: In our study, genotoxic potential of aqueous extract of $C$. coggygria leaves was assessed using the mussel micronucleus test. The test is based on the formation of micronuclei which indicates chromosomal DNA damage occurring as a result of either chromosome breakage or chromosome mis-segregation during mitosis. It is an easy-to-perform test which has proven sensitive to tannins or tannin containing extracts.

Results and conclusions: The aqueous extract had high hydrolysable tannin content but did not elucidate significant mutagenic effect. Our result might give an indication on the safe use of the plant.

\section{Introduction}

Cotinus coggygria Scop. (Rhus Cotinus L). (smoke tree, family Anacardiaceae) is a widely distributed shrub. Its area extends from, the Mediterranean, Moldova and the Caucasus, to central China and the Himalayas [1]. In recent ethnopharmacology, it is used for counteringdiarrhea, paradontosis, and gastric and duodenalulcers [2], healing skin disorders [3] or as mouth wash [4]. When testing antibacterial capacity of home-made mouthwash from C. coggygria, Ferazzano, et al. [5] demonstrated strong antimicrobial activity against selected oral pathogenic bacterial strains such as Streptococcus sobrinus or S. mutans. In vitro studies have proven its antibacterial capacity against pathogenic bacteria such as Staphylococcus aureus [6].

Total phenols, flavonoids and tannins were determined as the main group of biologically active compounds in eth$\mathrm{yl}$-acetate and methanol extracts of various parts of the plant [7]. There are studies available reporting on the direct genotoxic effect of tannins [8]. Although $C$. coggygria has been long used as a medicinal herb, its potential genotoxicity has only recently been addressed $[9,10]$. While in recent decades there has been a growing public interest in the use of herbs and herbal medicinal products both in developing and developed countries, the toxicity of several traditional medicinal herbs has not been completely and comprehensively evaluated. Sponchiado, et al. [11] for example discuss that some plants frequently used in folk medicine have already proven potentially genotoxic requiring the evaluation of genotoxicity. As such, the aim of the study was to assess the genotoxic potential of $C$. coggygria aqueous extract using the mussel micronucleus test (MNT). This test is based on the formation of micronuclei which indicates chromosomal DNA damage occurring as a result of either chromosome breakage or chromosome mis-segregation during mitosis [12]. The test is cost-efficient, easy-to-perform and found sensitive to tannins or plant extracts with high tannin content in genotoxicological studies $[13,14]$.

\section{Material and Methods}

C. coggygria sample was collected in July in the Pécsely-basin, karstic region of the Balaton Highlands, West of Hungary. Leaves were air-dried for 3 days at room temperature $\left(20-24^{\circ} \mathrm{C}\right)$. For the preparation of aqueous extracts, 60 grams of air-dried leaves were extracted with $1000 \mathrm{ml}$ of deionised

*Corresponding author: Nora Kováts, Department of Limnology, University of Pannonia, 200 Veszprém, Egyetem str. 10, Hungary, Tel: +36-88-624747, Fax: +36-88-624747

Accepted: July 22, 2019

Published online: July 24, 2019

Citation: Eck-Varanka B, Kováts N, Horváth E, et al. (2019) Assessing Genotoxic Potential of Cotinus Coggygria Scop: Using the Mussel Micronucleus Test. J Bot Res 2(1):57-59 
water by shaking for $24 \mathrm{~h}$ at room temperature.

In the micronucleus test, Unio pictorum (painter's mussel) specimens with length of $5-8 \mathrm{~cm}$ were used. Mussels were collected in Lake Balaton (Hungary) and were acclimatized for 1 month prior to the test. During acclimatisation, they were kept in a flow-through aquarium at the facility of the Balaton Limnological Research Centre. In the flow-through aquarium, Lake Balaton water was used, therefore continuous food supply was also provided.

Treatments were performed in aquaria of 31 volume, in 3 replicates. Each aquarium contained 10 specimens. Aquaria were aerated during the experiment; temperature was set at $22{ }^{\circ} \mathrm{C}$ ). In the first experiment, $6 \mathrm{~g} / \mathrm{l}$ concentration was used, but this concentration proved to be lethal. Further on, $1 \mathrm{~g} / \mathrm{l}$ and $0.1 \mathrm{~g} / \mathrm{l}$ concentrations were applied.

Exposure was 4 days. As in our previous tests plant extracts proved to be highly degradable [14], semi-static test was conducted: Sample was renewed after 2 days. After the pre-set exposure, haemolymph was taken from the posterior adductor. $1 \mathrm{ml}$ of haemolymph was mixed with $0.3 \mathrm{ml} 10 \%$ acetic acid in methanol as a fixative and centrifuged at $1000 \mathrm{rpm}$ for 5 minutes. The supernatant was discarded and the rest was fixed in $1 \mathrm{ml} \mathrm{80 \%} \mathrm{ethanol.} \mathrm{This} \mathrm{ensures}$ that the sample can be kept refrigerated for several weeks. When processing the samples, refrigerated samples are centrifuged again at $1000 \mathrm{rpm}$ for 5 minutes. For assessing the micronucleus ratio, the sample was smeared onto a microscope slide and allowed to dry. Slides were fixed in $80 \%$ methanol, air dried and stained with $5 \%$ Giemsa in distilled water for 20 minutes. Photos were taken by a Zeiss Axio Scope A1 microscope with an Axio Cam ICC1 camera and Zen 2011 program at $400 \times$ magnification. 1000 cells/specimen were counted, micronuclei (MN) were identified according to Bolognesi and Fenech [12]. Robust ANOVA of Welch with Tamahane T2 post hoc test was used to compare the mean $\mathrm{MN}$ numbers between the treatments. The difference in mean $\mathrm{MN}$ numbers of control and $C$. coggygria extract was determined using Students t-test.

Total tannin concentration was determined from air dried plant material [15]. Finely ground plant material (100 mg) was extracted with $5 \mathrm{ml}$ of $70 \%$ acetone, after 1 hour $0.5 \mathrm{ml}$ of supernatant was collected, and $0.5 \mathrm{ml}$ distilled water was added. Then $5 \mathrm{ml}$ of $\mathrm{Na}_{2} \mathrm{CO}_{3} 2 \% \mathrm{w} / \mathrm{v}$ (in $0.1 \mathrm{~N} \mathrm{NaOH}$ ), and after $5 \mathrm{~min} 0.5 \mathrm{ml}$ Folin-Ciocalteu reagent was added. After 120 min absorbance was measured at $760 \mathrm{~nm}$.

Hydrolysed tannin concentration was determined from aqueous extracts [16]. $50 \mathrm{ml}$ extract $(1 \mathrm{~g} / \mathrm{l})$ was mixed with $1 \mathrm{ml}$ Folin-phenol reagent and $10 \mathrm{ml}$ carbonate- tartrate. 30 min at $4{ }^{\circ} \mathrm{C}$ was allowed for colour development. Absorbance was measured at $700 \mathrm{~nm}$. In both measurements tannic acid solutions were used as standards.

\section{Results and Discussions}

Total tannin and hydrolysable tannin content of the dried

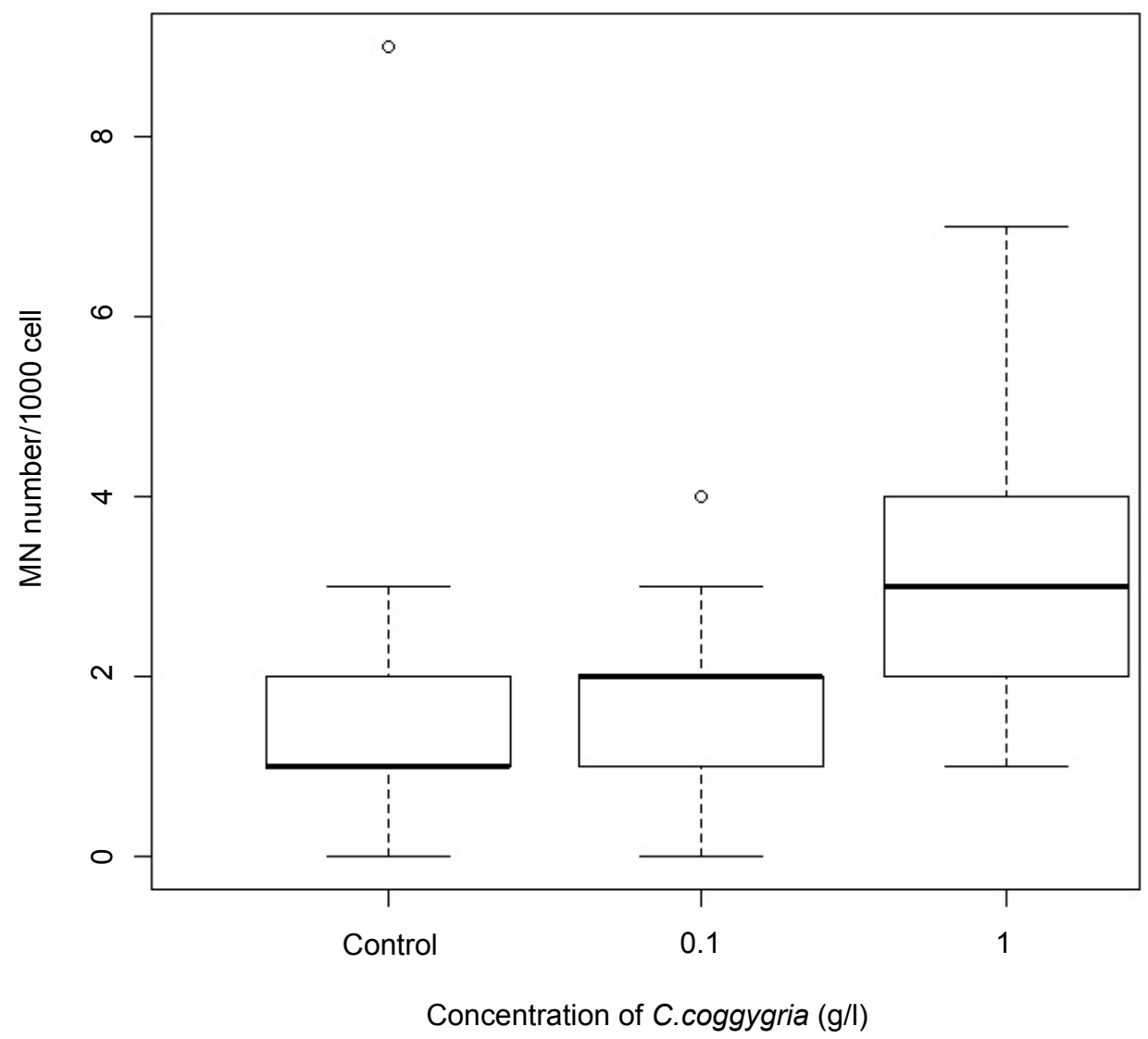

Figure 1: Number of micronuclei per 1000 cells, in different concentration of the aqueous extract of $C$. coggygria. 
aerial part was $150.03 \mathrm{mg} / \mathrm{g}$ and $66.35 \mathrm{mg} / \mathrm{g}$, respectively. However, aqueous extract of $C$. coggygria had no significant micronuclei induction, number of micronuclei/1000 cells was 2.1 in the control, 1.8 in the $0.1 \mathrm{~g} / \mathrm{l}$ and 3.3 in the $1 \mathrm{~g} / \mathrm{l}$ extract (Welch-ANOVA: $d f=2, F=1.3424, p=0.2787$, t-test: $p=0.8655$ between the control and the $0.1 \mathrm{~g} / \mathrm{l}, \mathrm{p}=0.112$ between the control and the $1 \mathrm{~g} / \mathrm{l}$ and $\mathrm{p}=0.0697$ between the $0.1 \mathrm{~g} / \mathrm{l}$ and the $1 \mathrm{~g} / \mathrm{l}$ concentration) (Figure 1).

It has been reported that methanol extract of $C$. coggygria in a concentration of $5 \%$ was clearly genotoxic, inducing sex-linked recessive lethal mutations on the X-chromosome of Drosophila melanogaster males $[9,10]$. On the other hand, post-treatment with lower concentration $(2 \%)$ of the methanol extract was effective in reducing genotoxicity [10]. Drosophila melanogaster has been widely used in a number of studies on genotoxicity of various compounds, including plant extracts, due to the similarity of metabolic pathways between Drosophila and mammals [17]. using $U$. tumidus as test organism. It was demonstrated that tannin concentrations of 1 and $5 \mu \mathrm{M}$ significantly decreased the amount of lesions induced by $\mathrm{H}_{2} \mathrm{O}_{2}$ while higher concentrations triggered single strand breaks in the DNA of the digestive gland of the mussels. Similar concentrationdependency was reported in a further study [8]. Azqueta and Collins [18] in their review discuss the effect of polyphenols and conclude that in general, while low concentrations can decrease DNA damage, high concentrations might themselves induce DNA damage. It should be noted, however, that all the above mentioned studies used methanol extract; therefore no data are available on the potential genotoxicity of the aqueous extract of $C$. coggygria.

\section{Conclusion}

The World Health Organisation [19] recommends the safety monitoring of herbal medicines/traditional medicines. In our study aqueous extract was used, somewhat mimicking the mode of preparation when C. coggygria is used as a tea or infusion. Our result might give an indication on the safe use of the plant.

\section{Competing Interests}

Authors have declared that no competing interests exist.

\section{Authors' Contributions}

Bettina Eck-Varanka managed the literature searches, performed the micronucleus tests and the statistical analysis; Nora Kováts designed the study and wrote the first draft of the manuscript; Eszter Horváth revised the test protocol and evaluated the data; Katalin Hubai performed analytical and maintaining test organisms and participated in the tests. All authors read and approved the final manuscript.

\section{References}

1. Novaković M, Vučković I, Janaćković P, et al. (2007) Chemical
Similar pattern was experienced by Labieniec, et al. [13], measurements; Gábor Paulovits was in charge of collecting

composition, antibacterial and antifungal activity of the essential oils of cotinus coggygria from Serbia. J Serb Chem Soc 72: 1045.

2. Ivanova D, Gerova D, Chervenkov T, et al. (2005) Polyphenols and antioxidant capacity of Bulgarian medicinal plants. J Ethnopharmacol 96: 145-150.

3. Redzic S (2010) Wild medicinal plants and their usage in traditional human therapy (Southern Bosnia and Herzegovina, W. Balkan). J Med Plants Res 4: 1003-1027.

4. Leporatti ML, Ivancheva S (2003) Preliminary comparative analysis of medicinal plants used in the traditional medicine of Bulgaria and Italy. J Ethnopharmacol 87: 123-142.

5. Ferrazano GF, Roberto L, Catania MR, et al. (2013) Screening and scoring of antimicrobial and biological activities of italian vulnerary plants against major oral pathogenic bacteria. EBCAM 2013: 1-10.

6. Tunç K, Hoş A, Güneş B (2013) Investigation of antibacterial properties of cotinus coggygria from Turkey. Pol J Environ Stud 22: 1559-1561.

7. Matić S, Stanić S, Mihailović M, et al. (2015) Cotinus coggygria scop: An overview of its chemical constituents, pharmacological and toxicological potential. SJBS 23: 452-461.

8. Labieniec M, Gabryelak T (2004) Response of DNA, proteins and membrane bilayer in the digestive gland cells of freshwater mussel unio tumidusto tannins exposure. Toxicol In Vitro 18: 773-781.

9. Stanić S, Matić S, Solujić S, et al. (2009) Genotoxicity testing of the methanol extract of the plant cotinus coggygria and gallic acid on drosophila melanogaster. Arch Biol Sci 61: 261-266.

10. Stanić S, Matić S, Đelić G, et al. (2011) Study of genotoxicity and antigenotoxicity of the cotinus coggygria scop methanol extract by drosophila melanogaster sex-linked recessive lethal test. Russ J Genet 47: 770-774.

11. Sponchiado G, Adam ML, Silva CD, et al. (2016) Quantitative genotoxicity assays for analysis of medicinal plants: A systematic review. J Ethnopharmacol 178: 289-296.

12. Bolognesi C, Fenech M (2012) Mussel micronucleus cytome assay. Nat Protoc 7: 1125-1137.

13. Labieniec M, Gabryelak T, Falcioni G (2003) Antioxidant and prooxidant effects of tannins in digestive cells of the freshwater mussel unio tumidus. Mut Res 539: 19-28.

14. Eck-Varanka B, Kováts N, Hubai K, et al. (2015) Genotoxic effect of lythrum salicaria extract determined by the mussel micronucleus test. Acta Biol Hung 66: 460-463.

15. Graça MAS, Bärlocher F, Gessner MO (2005) Methods to study litter decomposition: A practical guide. Springer, Netherlands.

16. American Public Health Association (1998) Standard methods for examination of water and wastewater. $\left(20^{\text {th }}\right.$ edn), United Book Press, USA.

17. Stamenković-Radak M, Andjelković M (2016) Studying genotoxic and antimutagenic effects of plant extracts in drosophila test systems. Botanica Serbica 40: 21-28.

18. Azqueta A, Collins A (2016) Polyphenols and DNA damage: A mixed blessing. Nutrients 8: 785.

19. World Health Organization (2004) WHO guidelines on safety monitoring of herbal medicines in pharmacovigilance systems.

DOI: $10.36959 / 771 / 561$

Copyright: (C) 2019 Eck-Varanka B, et al. This is an open-access article distributed under the terms of the Creative Commons Attribution License, which permits unrestricted use, distribution, and reproduction in any medium, provided the original author and source are credited.
SCHOLARS.DIRECT 